\title{
STREPTOCOCCAL AGGLUTININS AND ANTISTREPTOLYSINS IN RHEUMATOID (ATROPHIC) ARTHRITIS
}

\author{
By JOHN E. BLAIR AND FRANCES A. HALLMAN \\ (From the Laboratory Division, Hospital for Joint Diseases, Nere York City)
}

(Received for publication April 8, 1935)

Numerous attempts during the past several years to isolate bacteria of possible etiologic significance from the blood, synovial fluid, or tissues of patients with rheumatoid (atrophic) arthritis have yielded inconsistent results (1). In general, the lack of uniformity in the results of bacteriologic studies in this disease is striking.

Nevertheless, a suggestion of a possible relationship of hemolytic streptococci to rheumatoid arthritis was offered by the demonstration by Nicholls and Stainsby (2) of agglutinins for hemolytic streptococci in high titer in the blood serum of a majority of patients with this disease. Several subsequent reports (3-8) confirm in general the results of Nicholls and Stainsby, and show that the tendency of hemolytic streptococci to be agglutinated by sera from cases of rheumatoid arthritis is not restricted alone to the "typical strain" of Cecil, Nicholls, and Stainsby (9), but that the reaction is characteristic of beta (hemolytic) streptococci as a group.

Following infection by hemolytic streptococci, the blood serum contains streptococcal antihemolysin (antistreptolysin) in high titer. This was demonstrated by Todd (10) and later confirmed by Coburn and Pauli (11), working in conjunction with Todd, and by Myers and Keefer (12), in such infections as acute follicular tonsillitis, scarlet fever, erysipelas, and acute rheumatic fever. Wilson, Wheeler, and Leask (13) reported that following streptococcal infections the average antistreptolysin titer was definitely higher than in normal subjects. Seegal and Lyttle (14) found high antistreptolysin titers in a large percentage of a series of cases of acute glomerular nephritis.

Inasmuch as the demonstration of agglutinins for hemolytic streptococci in the serum of patients with rheumatoid arthritis is at least suggestive of some relation of these organisms to this disease, it appeared that an investigation of the antistreptolysin content of sera from patients with rheumatoid arthritis might be of interest. Myers and Keefer (12), whose paper appeared soon after the inception of this work, claimed that "the sera of patients with rheumatoid, as well as other forms of arthritis, fell into a group which resembled that of normal individuals or patients with non-streptococcal infections."

It is the purpose of this communication, first, to add confirmation of the presence of agglutinins for hemolytic streptococci in high titer in the sera of patients with rheumatoid arthritis, and second, to demonstrate that a certain percentage of these sera contain antistreptolysin in titers above the normal range.

\section{AGGLUTINATION TESTS}

Cases studied. Agglutination tests were performed on 69 sera from 62 cases of typical rheumatoid arthritis. The patients in this group presented the typical syndrome of a chronic polyarthritis which tended to progress to ankylosis and deformity. All degrees of severity of the disease were included in the series. The duration of the disease ranged from 3 months to 36 years; the great majority of the cases were of one year's duration or over. The age of the patients, including two children with Still's disease, ranged from 6 to 68 years; three-quarters of the group were under 50 years of age, and about half of the group were in the fourth and fifth decades.

As controls, 129 sera from 125 persons presenting a variety of infectious and non-infectious, orthopedic, medical, and surgical conditions were employed. These included hypertrophic arthritis, spondylitis ankylopoietica (of the Marie-Struempell or Bechterew type), gonorrheal arthritis, osteomyelitis, rheumatic fever, proven infections by hemolytic streptococci, and miscellaneous other conditions. The age distribution of the control series was similar to that of the patients with rheumatoid arthritis. 
TABLE I

Agglutination by sera from cases of theumatoid arthritis

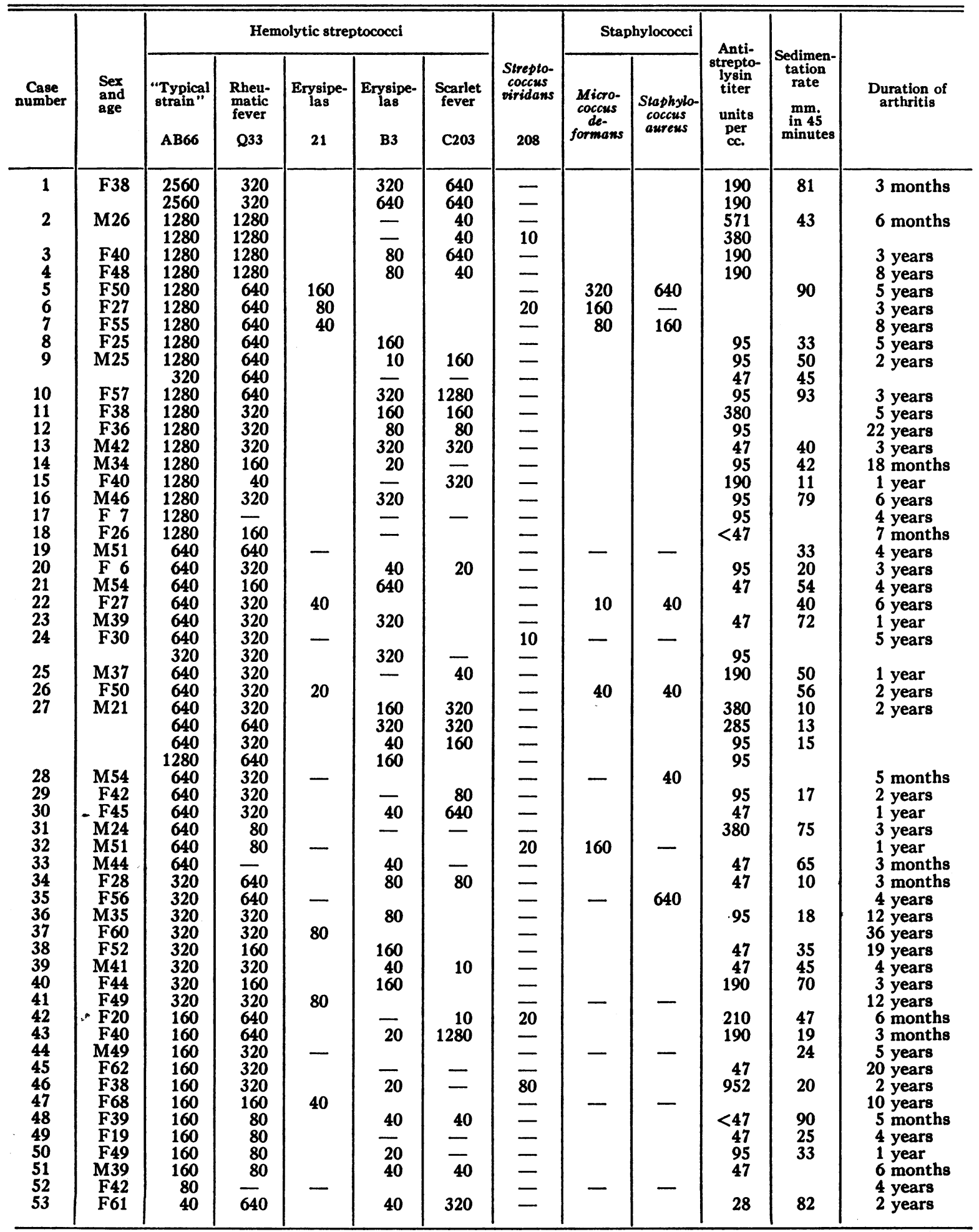


TABLE I (Continued)

\begin{tabular}{|c|c|c|c|c|c|c|c|c|c|c|c|c|}
\hline \multirow[b]{2}{*}{$\begin{array}{c}\text { Case } \\
\text { number }\end{array}$} & \multirow[b]{2}{*}{$\begin{array}{l}\text { Sex } \\
\text { and } \\
\text { age }\end{array}$} & \multicolumn{5}{|c|}{ Hemolytic streptococci } & \multirow{2}{*}{$\begin{array}{l}\text { Strepto- } \\
\text { cocccus } \\
\text { viridans }\end{array}$} & \multicolumn{2}{|c|}{ Staphylococci } & \multirow{2}{*}{$\begin{array}{c}\text { Anti- } \\
\text { strepto- } \\
\text { lysin } \\
\text { titer } \\
\\
\text { units } \\
\text { per. } \\
\text { cc. }\end{array}$} & \multirow{2}{*}{ 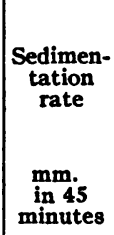 } & \multirow[b]{2}{*}{$\begin{array}{c}\text { Duration of } \\
\text { arthritis }\end{array}$} \\
\hline & & $\mid \begin{array}{c}\text { "Typical } \\
\text { strain" } \\
\text { AB66 }\end{array}$ & $\begin{array}{c}\begin{array}{c}\text { Rheu- } \\
\text { matic } \\
\text { fever }\end{array} \\
\mathbf{Q 3 3}\end{array}$ & $\begin{array}{c}\text { Erysipe- } \\
\text { las } \\
21\end{array}$ & 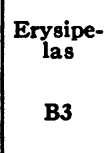 & $\begin{array}{c}\begin{array}{c}\text { Scarlet } \\
\text { fever }\end{array} \\
\text { C203 }\end{array}$ & & $\begin{array}{l}\text { Micro- } \\
\text { coccus } \\
\text { de- } \\
\text { formans }\end{array}$ & $\begin{array}{l}\text { Slaphylo- } \\
\text { cocccus } \\
\text { aureus }\end{array}$ & & & \\
\hline $\begin{array}{l}54 \\
55 \\
56 \\
57 \\
58 \\
59 \\
60 \\
61 \\
62\end{array}$ & $\begin{array}{r}\text { F57 } \\
\text { F54 } \\
\text { M47 } \\
\text { F67 } \\
\text { M50 } \\
\text { M18 } \\
\text { F47 } \\
\text { F34 } \\
\text { F22 }\end{array}$ & $\begin{array}{l}40 \\
40 \\
= \\
= \\
= \\
=\end{array}$ & $\begin{array}{r}80 \\
80 \\
160 \\
= \\
= \\
= \\
=\end{array}$ & 二 & $\begin{array}{r}20 \\
160 \\
=\end{array}$ & $\begin{array}{l}20 \\
40 \\
= \\
- \\
\overline{640}\end{array}$ & $\begin{array}{l}= \\
= \\
= \\
=\end{array}$ & 80 & $\begin{array}{r}1280 \\
320\end{array}$ & $\begin{array}{r}47 \\
0 \\
133 \\
190 \\
\\
<47 \\
95\end{array}$ & $\begin{array}{r}65 \\
20 \\
8 \\
38\end{array}$ & $\begin{array}{c}7 \text { years } \\
3 \text { years } \\
10 \text { years } \\
9 \text { months } \\
3 \text { months } \\
3 \text { months } \\
7 \text { years } \\
4 \text { years } \\
5 \text { years }\end{array}$ \\
\hline
\end{tabular}

The clinical diagnosis of Cases Number 17 and 20 is Still's disease. In the instances where more than one sample of serum was obtained, the time intervals between taking of the samples was as follows: Number 1-20 days; Number 2-

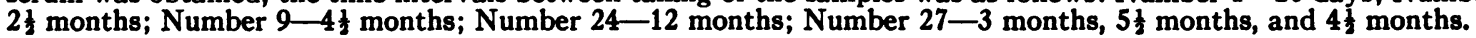

\section{Technic of agglutination tests}

The organisms employed in the agglutination tests were:

Hemolytic streptococci:

"AB66"-Cecil's "typical strain," isolated from the blood of a patient with rheumatoid arthritis.

"Q33" - a rheumatic fever strain, "from the tonsillar exudate of a patient who had suffered for months from severe polyarthritis and carditis with congestive failure" (15).

" 21 "-from a case of erysipelas.

"B3"-from a case of erysipelas.

"C203"-from a case of scarlet fever.

Streptococcus viridans:

" 208 "-isolated in this laboratory from the blood in a typical case of subacute bacterial endocarditis.

Staphylococci :

"Micrococcus deformans"-isolated by Crowe from the urine of a patient with rheumatoid arthritis.

Staphylococcus aureus " 182 "-isolated in this laboratory from the blood stream in a fatal case of infected sinus thrombosis.

For their courtesy in supplying certain of these strains, our thanks are due to Dr. W. J. Stainsby, for "AB66"; to Dr. H. F. Swift, for "Q33"; to Dr. K. E. Birkhaug, for " 21 "; to Dr. M. H. Dawson, for "B3" and " $\mathrm{C} 203$ "; and to Dr. H. W. Crowe, for Micrococcus deformans.

The sera used for the tests were obtained under aseptic precautions and kept in sterile tubes at $4^{\circ} \mathrm{C}$. All of the sera were tested with Cecil's " typical strain," Q33, one of the erysipelas strains, and Streptococcus viridans. The scarlet fever strain, C203, was used in agglutination tests with
114 sera, and the two staphylococcus strains with 80 sera.

In about half of the agglutination tests, living 24-hour cultures in bacto-heart-infusion broth were employed. Subsequently, younger cultures (16 to 20 hours old) in "streptolysin broth" were used. This medium was made according to the formula described by Swift and Hodge (16) and was found to give excellent diffuse growth. A small series of tests was also made with heat-killed suspensions in "streptolysin broth." Equally good results were obtained with antigens prepared by all three methods. The suspensions were diluted with physiological salt solution to the desired turbidity.

Serial dilutions of the sera were made in serological tubes with physiological salt solution, and an equal volume of bacterial suspension was added to each tube, to give final dilutions ranging

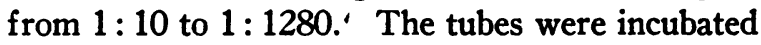
in a water bath at $56^{\circ} \mathrm{C}$. for two hours, then transferred to the refrigerator, at $4^{\circ} \mathrm{C}$. The titer was read after holding the tubes in the refrigerator overnight. The last dilution howing definite clumping of the organisms was taken as representing the agglutination titer.

\section{Results of agglutination tests}

Rheumatoid arthritis. The results of agglutination tests with sera from cases of rheumatoid arthritis are shown in Table $I$. Included in the table, for comparison, are the antistreptolysin 
titers and sedimentation rates. ${ }^{1}$ Sixty-nine sera from 62 patients were employed in the tests. Of these sera, 59 or 84 per cent (representing 82 per cent of the patients) caused agglutination of Cecil's " typical strain" streptococcus (AB66) in a titer of $1: 160$ or higher. With few exceptions, agglutination of AB66 was accompanied by agglutination of the streptococcus from rheumatic fever (Q33), and nearly one-fifth of the sera gave a higher titer with $Q 33$ than with AB66. A total of 60 ( 87 per cent) sera (representing 85 per cent of the patients) caused agglutination of $\mathrm{AB} 66$ or $\mathrm{Q33}$, or both, in a titer of $1: 160$ or higher. The trend of the agglutination titers obtained with the erysipelas and scarlet fever strains was generally appreciably lower than the titers obtained with the "typical strain" or with Q33.

Six of the sera caused agglutination of the strain of Streptococcus viridans used, the highest titer obtained being $1: 80$.
In contrast to the large number of high agglutination titers obtained in the group of rheumatoid arthritis, are the many negative tests obtained with the sera of these "control" groups. When agglutination occurred, the titers obtained with Q33 usually ran parallel to the titers obtained with AB66, and the scattered agglutination titers obtained with the other hemolytic streptococci were generally appreciably lower.

It may be noted that included among the controls are sera from six cases of spondylitis ankylopoietica (of the Marie-Struempell or Bechterew type) and from sixteen cases of hypertrophic arthritis or arthritis of the sacro-iliac articulations. Sera from three cases of spondylitis ankylopoietica and from three cases of hypertrophic arthritis agglutinated $\mathrm{AB} 66$ or $\mathrm{Q} 33$, or both, in dilutions of from $1: 160$ to $1: 1280$. It is recognized that while the joints of the spinal column are sometimes affected in rheumatoid arthritis, all cases

TABLE II

Summary of agglutination of Cecil's "T ypical strain" streptococcus (AB66) and of Q33

\begin{tabular}{|c|c|c|c|c|c|c|c|c|c|c|c|}
\hline & $\begin{array}{c}\text { Num- } \\
\text { ber of } \\
\text { indi- } \\
\text { viduals }\end{array}$ & $\begin{array}{c}\text { Total } \\
\text { num- } \\
\text { ber of } \\
\text { sera }\end{array}$ & $\begin{array}{c}\text { Nega- } \\
\text { tive }\end{array}$ & $1: 10$ & $1: 20$ & $1: 40$ & $1: 80$ & $1: 160$ & $1: 320$ & $1: 640$ & $\begin{array}{c}1: 1280 \\
\text { and over }\end{array}$ \\
\hline 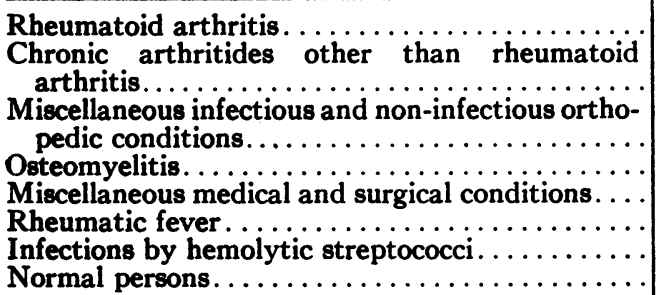 & $\begin{array}{r}62 \\
31 \\
35 \\
14 \\
11 \\
24 \\
5 \\
5\end{array}$ & $\begin{array}{r}69 \\
32 \\
35 \\
14 \\
11 \\
25 \\
7 \\
5\end{array}$ & $\begin{array}{r}6 \\
15 \\
29 \\
8 \\
9 \\
8 \\
1 \\
2\end{array}$ & $\begin{array}{l}0 \\
1 \\
0 \\
1 \\
0 \\
0 \\
0 \\
0\end{array}$ & $\begin{array}{l}0 \\
0 \\
0 \\
0 \\
1 \\
0 \\
0 \\
0\end{array}$ & $\begin{array}{l}0 \\
0 \\
0 \\
1 \\
0 \\
2 \\
0 \\
0\end{array}$ & $\begin{array}{l}3 \\
2 \\
1 \\
0 \\
1 \\
1 \\
0 \\
1\end{array}$ & $\begin{array}{l}6 \\
1 \\
\\
0 \\
0 \\
0 \\
2 \\
0 \\
2\end{array}$ & $\begin{array}{r}10 \\
6 \\
3 \\
1 \\
0 \\
4 \\
2 \\
0\end{array}$ & $\begin{array}{r}23 \\
4 \\
4 \\
1 \\
0 \\
0 \\
5 \\
4 \\
0\end{array}$ & $\begin{array}{l}1 \\
3 \\
0 \\
3 \\
0 \\
0\end{array}$ \\
\hline
\end{tabular}

Seventeen of the sera were employed in agglutination tests with the two strains of staphylococci. Seven contained no agglutinins for these organisms, and ten caused agglutination of one or both strains, the titers for Micrococcus deformans ranging from $1: 10$ to $1: 320$, and for Staphylococcus aureus from $1: 40$ to $1: 640$.

"Control" groups. A summary of the results of agglutination tests with sera from the various disease groups other than rheumatoid arthritis, and from normal individuals, appears in Table II.

1 The sedimentation rate was determined according to the technic described by Weiss (17). of spondylitis ankylopoietica need not have a rheumatoid basis. Furthermore, while cases of the hypertrophic type are generally of a noninfectious origin (idiopathic hypertrophic arthritis), it is known that damage to the tissues of a joint by a previous infection may occasionally be the basis for the development of hypertrophic joint changes.

We obtained a somewhat larger percentage of high agglutination titers in our series with sera from cases of rheumatic fever than has been reported by others. High titers were obtained with the various hemolytic streptococci and sera from cases of proven infection by hemolytic streptococci. 
Of the 129 sera from cases other than rheumatoid arthritis, only 7 caused agglutination of Streptococcus viridans. These were: 1 bronchial asthma $(1: 10) ; 1$ gout $(1: 80) ; 1$ chronic osteomyelitis $(1: 20) ; 1$ rheumatic fever $(1: 40) ; 1$ chorea $(1: 40) ; 2$ proven infections by hemolytic streptococci $(1: 10$ and $1: 20)$.

About half of all the control sera which were tested against the two strains of staphylococci caused agglutination of one or both of the strains. The majority of the titers ranged from $1: 10$ to $1: 80$, although occasionally titers ranging up to $1: 1280$ were obtained.

\section{Agglutination by synovial fluid}

Nicholls and Stainsby (2) stated that they performed agglutination tests with "typical strain" streptococci and synovial fluid from three cases of chronic infectious arthritis. The agglutination titers obtained were $1: 640,1: 2560$, and $1: 5120$, respectively.
In our series, forty-four specimens of synovial fluid, from a variety of infectious and noninfectious arthropathies, were used in agglutination tests. The technic was the same as that for the sera, except that the final dilutions ranged from $1: 5$ to $1: 160$. In the event that agglutination occurred throughout the series, a second test was run, using dilutions up to $1: 5120$.

Twenty of the synovial fluids were from patients who had also furnished blood serum for agglutination tests. A comparison of the agglutination titers of the fluids and their corresponding sera is found in Table III. The source of the fluids is as follows : rheumatoid arthritis-5; gonorrheal arthritis-3; hypertrophic arthritis-3; chronic synovitis-3; tuberculous synovitis-2; luetic synovitis-1; miscellaneous conditions of joints-3.

The titers of three of the five fluids from rheumatoid arthritis were $1: 160,1: 640$, and $1: 5120$, respectively. The homologous sera in all three

TABLE III

Agglutination by serum and synovial fluid from same patient

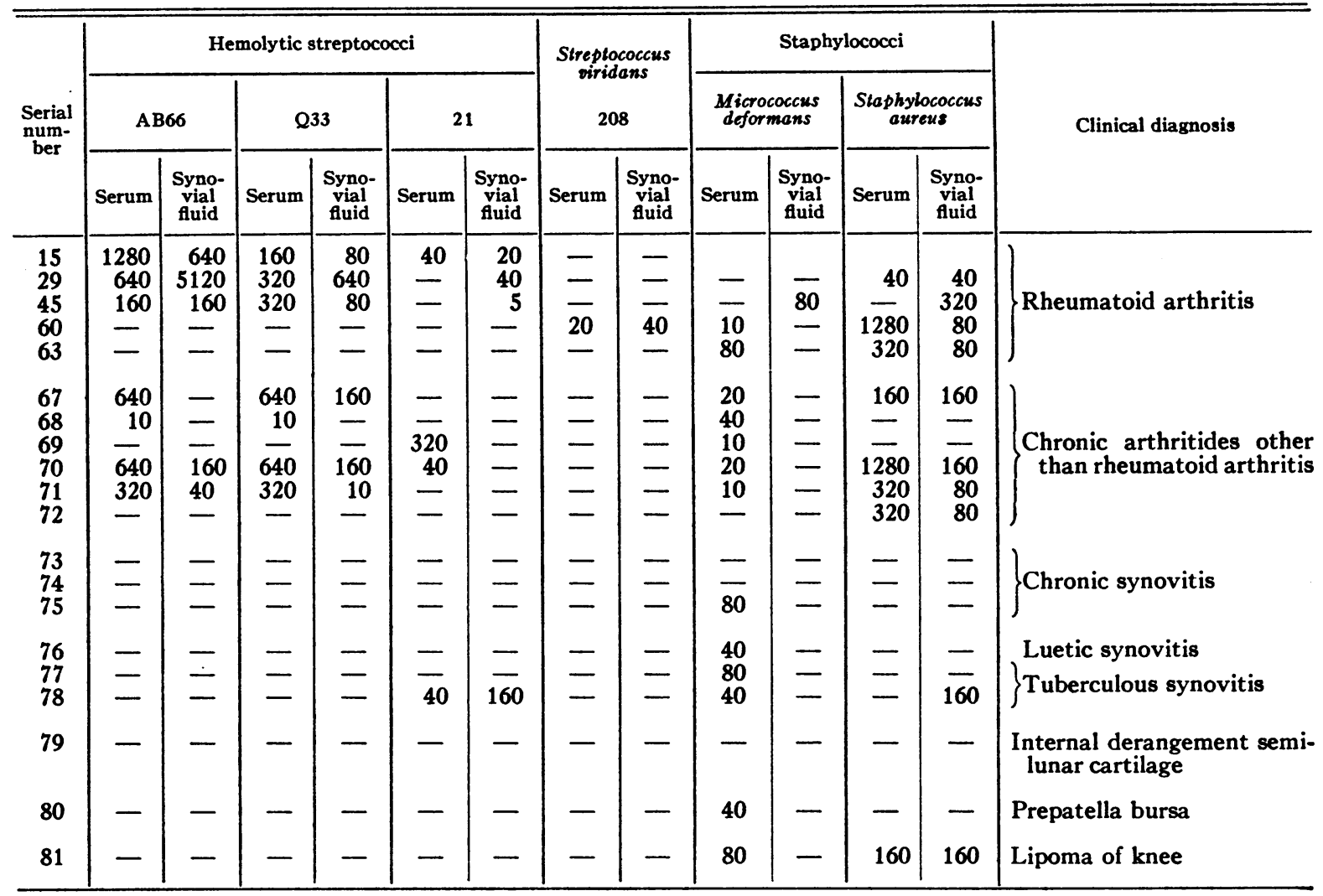


cases contained agglutinins in significant titer. Two synovial fluids and their corresponding sera contained no agglutinins for hemolytic streptococci.

A total of five of the 44 fluids caused agglutination of Cecil's "typical strain" streptococcus. Three of these were the fluids from rheumatoid arthritis described above; the other two were from cases of hypertrophic arthritis. Scattered agglutinations of Q33 and of an erysipelas strain occurred, usually in low titer, although three titers of $1: 160$, and one of $1: 640$ were obtained. These titers occurred with fluids from cases of gonorrheal arthritis and tuberculous synovitis (1:160) and from one case of hypertrophic arthritis $(1: 640)$. Streptococcus viridans was agglutinated only once-by a dilution of $1: 40$ of a synovial fluid from a case of rheumatoid arthritis; this fluid caused agglutination of no other streptococcus, but agglutinated Staphylococcus aureus in a dilution of $1: 80$.

It is interesting to note that 22 of the 44 fluids caused agglutination of Staphylococcus aureus. The titers of seven fluids were $1: 40$ or $1: 80$; the titers of fourteen fluids were $1: 160$, and one had a titer of $1: 320$. When both fluid and serum from the same patient were tested, agglutination occurred with both, with few exceptions, and usually the titer of the serum was higher than that of the fluid. Agglutination of Staphylococcus aureus occurred with some synovial fluids from all of the disease groups represented.

\section{Correlation between agglutination titer and cer- tain phases of rheumatoid arthritis}

Several attempts have been made to correlate the agglutination titer with various features of the disease $(2,3,4,6)$, such as its duration, number of joints involved, age of the patient, etc. We were unable to establish a correlation of the agglutination titer with any clinical aspects of the disease. We also found no correlation of the agglutination titer with the sedimentation rate, in confirmation of the reports of Dawson, Olmstead, and Boots (4) and of Keefer, Myers, and Oppel (5).

\section{Comment}

It appears to be reasonable to assume that an agglutination titer of $1: 160$ or higher is " signifi- cant," or indicative of infection by streptococci. This titer was considered to be of significance in rheumatoid arthritis by Gray and Gowen (3) and by Dawson (4), and their associates, while a significant titer of $1: 320$ was adopted by Nicholls and Stainsby (2), and by Cox and Hill (6). A titer of $1: 160$ is much higher than the titers which are commonly accepted as being diagnostically significant in such infections as typhoid fever, Brucellosis, and typhus fever.

The fact is well established that sera from the majority of patients with rheumatoid arthritis contain agglutinins in high titer for hemolytic streptococci, a finding which can hardly be explained as entirely fortuitous. Furthermore, sera from arthritic conditions other than rheumatoid arthritis do not give such consistently high titers.

Nicholls and Stainsby consider that the agglutination in high titer of their "typical strain" streptococcus by sera from cases of rheumatoid arthritis "appears to be a true immunological response," and that the results they have reported "lend strong support to the theory that the "typical strain' streptococcus is an important etiologic factor" in this disease. Dawson and his associates concluded that, while many of the features of the reaction are indicative of a true immunological response, the results obtained could be considered only as suggestive of an association of hemolytic streptococci with rheumatoid arthritis. Further suggestive evidence has been adduced, they believe, by their comparative study of agglutination and precipitation reactions, in which "a close approximation, but not an absolute agreement" is obtained in the results of the two tests.

It appears to be satisfactorily demonstrated that beta type streptococci, particularly such organisms as Cecil's “ typical strain," NY5, or Q33, are characteristically agglutinated by sera from patients with rheumatoid arthritis. Cox and Hill (6) found that no other organism which they used had as great a serologic specificity for sera from cases of atrophic arthritis as did Cecil's " typical strain." However, they employed only one other strain of hemolytic streptococcus (isolated from the stool of a patient with rheumatoid arthritis), and they discarded another strain (NY5) after a few tests, since it always gave parallel agglutinations with Cecil's streptococcus, but in a lesser degree. They felt that definite deductions as to the etiologic 
rôle of Cecil's "typical strain" would be premature. Wainwright (7), who used Cecil's " typical strain " and NY5, concludes that a positive agglutination "does not indicate of necessity a causal relationship between hemolytic streptococci and rheumatoid arthritis but it does suggest that streptococci play a rôle in this disease ... the frequency with which it [agglutination] occurs in rheumatoid arthritis is the most incriminating evidence thus far produced against the streptococcus in this disease and merits some consideration."

The assumption that the reaction is a true immunological response suggests that it can be used for diagnostic purposes. Gray and Gowen (3) believe that it " is undoubtedly of considerable value in differential diagnosis, particularly in osteoarthritis." Cox and Hill (6), on the other hand, point out that " ordinarily a laboratory procedure is unnecessary in establishing a diagnosis of arthritis," and feel, from the results of their series of tests, that while the test may be used occasionally in doubtful cases and under carefully controlled conditions, it is of doubtful value in prognosis or as an isolated laboratory procedure.

The agglutination reaction with hemolytic streptococci apparently can serve to confirm a clinical diagnosis of rheumatoid arthritis, but its use hardly seems necessary in the majority of cases, where the clinical signs and symptoms render the diagnosis quite apparent. However, in borderline cases which are difficult of clinical diagnosis, the frequency of high titers in rheumatoid arthritis, and the comparative infrequency of similar titers in other types of arthritis, make it possible to indicate a probable diagnosis, based upon the results of agglutination tests with hemolytic streptococci, such as Cecil's " typical strain" or a strain giving closely parallel results.

\section{ANTISTREPTOLYSIN TESTS}

In testing sera for their antistreptolysin content, Todd (10) titrated against a unit expressed in terms of the minimal hemolytic dose of streptolysin. Inasmuch as streptolysin produced by hemolytic streptococci of human origin is subject to reversible oxidation and reduction, and the filtrate is hemolytic only when in the reduced state, the hemolytic power of a given filtrate may not remain constant.
However, it has been demonstrated by Hodge and Swift (18) that under certain conditions the power of streptolysin to combine with antisera remains constant over a considerable period. Their method of titrating antisera in terms of the " constant combining power" of streptolysin thus assures a reasonable degree of accuracy and obviates the necessity of having to resort to repeated determinations of the hemolytic titer.

\section{Technic of antistreptolysin tests}

The streptolysin used throughout the tests was prepared from cultures of the scarlet fever strain of hemolytic streptococcus, C203, which was used in the agglutination tests described above.

The technic used was that described by Swift and Hodge for preparing streptolysin (16), and by Hodge and Swift for titrating the minimal hemolytic dose and combining power of streptolysin, and for determining the antistreptolysin content of serum in terms of the constant combining power of streptolysin (18).

Without going into the details of the technic, a few pertinent facts may be recorded. Streptolysin was reduced in vacuuo for 2 to 3 hours with 0.1 per cent of freshly ground sodium hydrosulfite, immediately after the 16 to 17 hour "streptolysin broth" culture had been filtered through a Seitz filter. The reduced streptolysin was immediately dispensed in sterile tubes or flasks, covered with a thick layer of sterile vaseline, and stored in the refrigerator.

Rabbit erythrocytes were used in all of these tests, as the red blood cells of other animal species have been found to give somewhat inconsistent results.

Streptolysin is "standardized" in terms of its constant combining power by determining the amount of streptolysin which is just inhibited by one antistreptolysin unit of a previously titrated serum of known antistreptolysin content.

Serum is titrated for its antistreptolysin content by determining that serum dilution which just inhibits hemolysis of $0.5 \mathrm{cc}$. of a 5 per cent suspension of twice washed rabbit erythrocytes by one combining unit of standardized streptolysin after incubation at $37^{\circ} \mathrm{C}$. for one hour. The antistreptolysin titer of a serum is recorded as 
the reciprocal of that dilution which just prevents hemolysis, as described above.

\section{Standards}

In tests of this type it is obvious that standards should be established for the titration of streptolysin and antistreptolysin, so that the results obtained in various laboratories may all be recorded in similar terms. Only by this means may adequate comparisons be made of published reports from different laboratories. Recognizing this fact, Todd (19) has set aside a quantity of serum of known antistreptolysin potency, to be used as an arbitrary standard in antistreptolysin determinations.

The streptolysin of Hodge and Swift was standardized "with a number of sera furnished by Dr. Coburn ... duplicates of these sera had been tested by Todd" (18). Through the courtesy of Dr. Hodge, samples of serum and of standardized streptolysin were obtained, and against these our own streptolysin and a few sera were standardized in a preliminary series of titrations. Recently, Dr. Todd kindly sent us some of his standard antistreptolysin serum which was used in a series of comparative tests with sera whose original titrations refer back to the standards supplied by Dr. Hodge. Thus checks on our streptolysin were obtained directly against Todd's standard serum, and indirectly against his standard, by means of serum supplied by Dr. Hodge.

Antistreptolysin titer of normal serum. In order to evaluate the results of antistreptolysin determinations, it is essential to know to what extent antistreptolysin is present in the serum of normal individuals, and to establish a normal value.

Todd (10), and Coburn and Pauli (11) have demonstrated that the maximum antistreptolysin titer of the serum of normal individuals is about 100 units per cubic centimeter. Parallel tests with Todd's serum and with sera which were titrated by the method of Hodge and Swift have shown that the value which we obtained for normal individuals is essentially equivalent to the value obtained by Todd. It would appear that, for the sake of exact comparison with other published results, the titers of antisera should be expressed in terms of some arbitrary standard, such as is represented by the serum which has been made available by Todd. Consequently, the titers recorded in this paper are given in terms of Todd's standard serum. Titers above 100 units per cc. are considered to be indicative of infection by hemolytic streptococci.

\section{Results of antistreptolysin tests}

Repeated tests have confirmed the assertions of Hodge and Swift (18) that the combining power of streptolysin remains constant over a considererable period of time (provided the streptolysin has been properly prepared, reduced, and stored in the cold), while during the same period the hemolytic titer may vary appreciably. Their statement has been repeatedly confirmed that the antistreptolysin titer of serum remains stable when the serum is kept sterile and cold.

The specificity of the antistreptolysin test ( 5 , 19) has been amply demonstrated by testing for their antistreptolysin content several sera from animals immunized to a variety of organisms. Practically without exception, the antistreptolysin titers of these immune sera were low (averaging 95 to 45 units or less per cc.). In addition, several human sera possessing high antistreptolysin titers were tested for staphylococcal antihemolysin. The low staphylococcal antihemolysin titers which were obtained confirms Todd's assertion that the hemolysins of streptococci and staphylococci are not serologically related (18).

Rheumatoid arthritis. Antistreptolysin determinations were done on 51 sera from 45 patients. The titers obtained are recorded in Table IV. Eighteen of these sera (representing 15 persons) gave titers definitely above the normal range (over 100 units per cc.) and the titers of the remaining 33 sera were within the normal range (100 units or less per cc.). It is interesting to note that, of the 18 sera giving high antistreptolysin titers, 17 also caused agglutination of either AB66 or Q33, or both, in significant titers. On the other hand, 29 sera which gave significant agglutination titers with these two streptococci possessed antistreptolysin titers within the normal range. Of five sera which gave little or no agglutination with AB66 or Q33, four also possessed normal antistreptolysin titers.

"Control" groups. Antistreptolysin determinations were done on 68 sera from 56 cases other 
TABLE IV

Antistreptolysin titers

\begin{tabular}{|c|c|c|c|c|c|}
\hline $\begin{array}{l}\text { Serial number } \\
\text { of serum }\end{array}$ & Units per cc. & $\begin{array}{l}\text { Approximate equivalent } \\
\text { in fraction of cc. }\end{array}$ & $\begin{array}{l}\text { Total number of } \\
\text { sera giving titers } \\
\text { indicated }\end{array}$ & Units per cc. & $\begin{array}{l}\text { Approximate equivalent } \\
\text { in fraction of cc. }\end{array}$ \\
\hline \multicolumn{3}{|c|}{ Proven infections by hemolytic streptococci } & \multicolumn{3}{|c|}{ Rheumatoid arthritis } \\
\hline & & $c c$ & \multirow{7}{*}{$\begin{array}{r}5 \\
13 \\
15 \\
1 \\
9 \\
1 \\
1 \\
4 \\
1 \\
1\end{array}$} & \multirow{7}{*}{$\begin{array}{r}<47 \\
47 \\
95 \\
133 \\
190 \\
210 \\
285 \\
380 \\
571 \\
952\end{array}$} & \multirow{7}{*}{$\begin{array}{c}c c . \\
0.0350 \\
0.0212 \\
0.0105 \\
0.0075 \\
0.0052 \\
0.0047 \\
0.0035 \\
0.0026 \\
0.0017 \\
0.0010\end{array}$} \\
\hline 1 & 95 & 0.0105 & & & \\
\hline 2 & 285 & 0.0035 & & & \\
\hline $3(1)$ & 285 & 0.0035 & & & \\
\hline & & 0.0020 & & & \\
\hline 4 (1) & $\begin{array}{l}475 \\
952\end{array}$ & $\begin{array}{l}0.0021 \\
0.0010\end{array}$ & & & \\
\hline \multirow{2}{*}{5 (1) } & \multirow{2}{*}{$\begin{array}{r}1146 \\
95\end{array}$} & \multirow{2}{*}{$\begin{array}{l}0.0008 \\
0.0105\end{array}$} & & & \\
\hline & & & \multicolumn{3}{|c|}{ Chronic arthritides other than rheumatoid arthritis } \\
\hline 6 & 380 & 0.0026 & \multirow{2}{*}{$\begin{array}{l}3 \\
8 \\
1 \\
1\end{array}$} & \multirow{2}{*}{$\begin{array}{r}47 \\
95 \\
114 \\
190\end{array}$} & \multirow{2}{*}{$\begin{array}{l}0.0212 \\
0.0105 \\
0.0087 \\
0.0052\end{array}$} \\
\hline 7 (1) & $\begin{array}{l}665 \\
571\end{array}$ & $\begin{array}{l}0.0015 \\
0.0017\end{array}$ & & & \\
\hline \multicolumn{3}{|c|}{ Rheumatic fever } & \multicolumn{3}{|c|}{ Miscellaneous orthopedic conditions } \\
\hline \multirow{10}{*}{$\begin{array}{r}8 \\
9 \\
10 \\
11 \\
12 \\
13 \\
14 \\
15 \\
16 \\
17 \\
18 \\
19 \\
20 \\
21 \\
22\end{array}$} & \multirow{11}{*}{$\begin{array}{r}47 \\
95 \\
95 \\
190 \\
190 \\
266 \\
266 \\
285 \\
285 \\
285 \\
285 \\
285 \\
342 \\
761 \\
1332\end{array}$} & \multirow{10}{*}{$\begin{array}{l}0.0212 \\
0.0105 \\
0.0105 \\
0.0052 \\
0.0052 \\
0.0037 \\
0.0037 \\
0.0035 \\
0.0035 \\
0.0035 \\
0.0035 \\
0.0035 \\
0.0029 \\
0.0013 \\
0.0007\end{array}$} & 1 & 47 & 0.0212 \\
\hline & & & 1 & 57 & 0.0175 \\
\hline & & & 1 & 95 & 0.0105 \\
\hline & & & \multirow{2}{*}{\multicolumn{3}{|c|}{ Osteomyelitis }} \\
\hline & & & & & \\
\hline & & & 1 & 47 & 0.0212 \\
\hline & & & $\begin{array}{l}1 \\
1\end{array}$ & $\begin{array}{r}95 \\
195\end{array}$ & $\begin{array}{l}0.0105 \\
0.0051\end{array}$ \\
\hline & & & 3 & 285 & 0.0035 \\
\hline & & & 1 & 380 & 0.0035 \\
\hline & & & \multicolumn{3}{|c|}{ Miscellaneous medical and surgical conditions } \\
\hline \multirow{2}{*}{23 (1) } & & & & 47 & 20012 \\
\hline & $\begin{array}{l}285 \\
437\end{array}$ & $\begin{array}{l}0.0035 \\
0.0023\end{array}$ & 4 & 47 & 0.0212 \\
\hline \multirow{3}{*}{$\begin{array}{r}24 \text { (1) } \\
\text { (2) } \\
\text { (3) }\end{array}$} & \multirow{3}{*}{$\begin{array}{l}285 \\
285 \\
190\end{array}$} & \multirow{3}{*}{$\begin{array}{l}0.0035 \\
0.0035 \\
0.0052\end{array}$} & \multicolumn{3}{|c|}{ Normal persons } \\
\hline & & & 4 & \multirow{2}{*}{$\begin{array}{l}47 \\
95\end{array}$} & \multirow{2}{*}{$\begin{array}{l}0.0212 \\
0.0105\end{array}$} \\
\hline & & & 1 & & \\
\hline & 380 & 0.0026 & & & \\
\hline (2) & 475 & 0.0021 & & & \\
\hline $\begin{array}{l}(3) \\
(4)\end{array}$ & $\begin{array}{l}761 \\
665\end{array}$ & $\begin{array}{l}0.0013 \\
0.0015\end{array}$ & & & \\
\hline (5) & 475 & 0.0021 & & & \\
\hline
\end{tabular}

than rheumatoid arthritis, representing a variety of orthopedic and medical conditions, and normal persons. Included in the control groups are 11 sera from 7 cases of proven infection by hemolytic streptococci; 25 sera from 18 cases of rheumatic fever; 23 sera from 22 miscellaneous orthopedic conditions (including 7 sera from 7 cases of osteomyelitis); 4 sera from 4 miscellaneous medical or surgical conditions; and 5 sera from 5 healthy persons, with no history of preceding infection by hemolytic streptococci. The antistreptolysin titers of these sera are recorded in Table IV.

Proven infections by hemolytic streptococci. Sera were obtained from five patients with acute mastoiditis, one patient with infected varicose ulcer, and one patient convalescing from scarlet 
fever. The first specimens of serum were obtained from all but one of the patients from one and one-half to eight weeks after the onset of infection. Hemolytic streptococci were isolated in every instance.

It is obvious that the titers obtained are considerably above the normal range and are confirmatory of the proven infection by hemolytic streptococci. In one case of mastoiditis, an originally high titer of 1146 units (20 days after mastoidectomy) was followed six months later by a normal titer of 95 units, when the patient had clinically recovered from the infection. The one serum from a case of mastoiditis which had a normal titer was obtained only four days after the onset of infection.

Rheumatic fever. Twenty-five sera from 18 patients with rheumatic fever were tested. The three sera which gave normal titers (100 units per cc. or less) were obtained from three patients at a time of inactivity of the disease. All three were in the hospital because of cardiovascular disease which followed an earlier acute rheumatic fever. None gave a history of an acute infection of the throat prior to the time of the antistreptolysin test. The titers of 22 sera from the 15 other patients were decidedly higher than normal. All of these patients had acute rheumatic fever, and all gave histories of acute infections of the upper respiratory tract just prior to the onset of the attack. The gradual rise in titer after an attack of acute rheumatic fever, and the subsequent fall in titer, coincident with clinical improvement are seen in three of the cases.

Miscellaneous other conditions. Of the 32 miscellaneous sera tested for antistreptolysin, only seven gave titers above normal. Two were from cases of spondylitis of the Marie-Struempell type. The other five were from cases of chronic osteomyelitis. The opportunity for secondary infection by streptococci in this type of case is obvious. The titers of five sera from normal healthy persons, with no history of immediately preceding infection by hemolytic streptococci, were well within the normal range.

\section{COMMENT}

The appearance of antistreptolysin in cases of proven hemolytic streptococcus etiology and in such diseases as rheumatic fever, scarlet fever, and erysipelas (whose streptococcal etiology is generally accepted) seems to follow a recent infection, or an acute exacerbation of an older process. Coburn and Pauli (11) have shown that in rheumatic fever antistreptolysin rises to a high titer soon after the onset of infection or a recrudescence of the disease, and drops with a return to the quiescent state.

The presence of antistreptolysin in titers above normal in some cases of rheumatoid arthritis is interesting and suggestive, in view of the present general tendency to assume some relationship of streptococci to this disease. The fact that rheumatoid arthritis is a chronic disease obviously precludes the possibility of obtaining a high percentage of antistreptolysin titers above the normal range. However, it may be pointed out that, with one exception, the sera from cases of rheumatoid arthritis which possessed high antistreptolysin titers also caused agglutination of hemolytic streptococci in significant titer. When positive in high titer, antistreptolysin determinations may serve as additional evidence of the recent association of hemolytic streptococci with rheumatoid arthritis.

\section{SUMMARY}

Agglutinins for hemolytic streptococci in high titer were demonstrated in the sera of a majority of patients ( 85 per cent) with rheumatoid arthritis. Agglutination of hemolytic streptococci in high titer by a large percentage of sera was not obtained in other chronic arthritides.

No correlation was found between the agglutination titer and the age of the patient, duration of the disease, number of joints involved, or sedimentation rate, in cases of rheumatoid arthritis.

Antistreptolysin was present in titers above the normal range in the sera of patients with proven infections by hemolytic streptococci, and with acute rheumatic fever. There was a tendency for the antistreptolysin titer to return to within the normal range some time after convalescence.

Antistreptolysin in titers definitely above normal were found in about one-third of the sera from patients with rheumatoid arthritis. With one exception, these high titers accompanied high agglutination titers.

The presence of agglutinins for hemolytic strep- 
tococci in sera from patients with rheumatoid arthritis is suggestive of an association of these organisms with this disease. Additional suggestive evidence may be offered by the presence of antistreptolysin, when it is found in titers above normal.

\section{BIBLIOGRAPHY}

1. Blair, J. E., and Hallman, F. A., Rheumatoid (atrophic) arthritis: Bacteriologic cultures of synovial fluid and of tissues. Arch. Int. Med., 1934, $53,87$.

2. Nicholls, E. E., and Stainsby, W. J., Streptococcal agglutinins in chronic infectious arthritis. J. Clin. Invest., 1931, 10, 323.

Further studies on the agglutination reaction in chronic arthritis. J. Clin. Invest., 1933, 12, 505.

3. Gray, J. W., and Gowen, C. H., The rôle of the streptococcus in arthritis deformans (an improved cultural method). Am. J. M. Sc., 1931, 182, 682.

Gray, J. W., Fendrick, E., and Gowen, C. H., Rheumatic fever and rheumatoid arthritis from the laboratory point of view. Texas State J. Med., 1932, 28, 317.

4. Dawson, M. H., Olmstead, M., and Boots, R. H., Agglutination reactions in rheumatoid arthritis. I. Agglutination reactions with Streptococcus hemolyticus. J. Immunol., 1932, 23, 187.

II. The Nature and significance of agglutination reactions with Streptococcus hemolyticus. J. Immunol., 1932, 23, 205.

Dawson, M. H., Olmstead, M., and Jost, E. L., Agglutination reactions in rheumatoid arthritis. III. Comparison of agglutinins and precipitins for Streptococcus hemolyticus in rheumatoid arthritis sera. J. Immunol., 1934, 27, 355.

5. Keefer, C. S., Myers, W. K., and Oppel, T. W., Streptococcal agglutinins in patients with rheumatoid (atrophic) arthritis and acute rheumatic fever. J. Clin. Invest., 1933, 12, 267.

6. Cox, K. E., and Hill, D. F., Chronic arthritis: Serologic and clinical studies. Arch. Int. Med., 1934, 54, 27.

7. Wainwright, C. W., The treatment of chronic rheumatoid arthritis with streptococcus vaccine. On the basis of skin sensitivity. J. A. M. A., 1934, 103, 1357.
8. Ashworth, O. O., Bacteriology and treatment of rheumatoid arthritis. Virginia M. Monthly, 1932, 59, 452.

9. Cecil, R. L., Nicholls, E. E., and Stainsby, W. J., The bacteriology of the blood and joints in chronic infectious arthritis. Arch. Int. Med., 1929, 43, 571.

10. Todd, E. W., Antihaemolysin titres in haemolytic streptococcal infections and their significance in rheumatic fever. Brit. J. Exper. Path., 1932, 13, 248.

11. Coburn, A. F., and Pauli, R. H., Studies on the relationship of Streptococcus hemolyticus to the rheumatic process. III. Observations on the immunological responses of rheumatic subjects to hemolytic streptococcus. J. Exper. Med., 1932, 56, 651.

12. Myers, W. K., and Keefer, C. S., Antistreptolysin content of the blood serum in rheumatic fever and rheumatoid arthritis. J. Clin. Invest., 1934, 13, 155.

13. Wilson, M. G., Wheeler, G. W., and Leask, M. M., Antistreptolysin content of blood serum of children. Its significance in rheumatic fever. Proc. Soc. Exper. Biol. and Med., 1934, 31, 1001.

14. Seegal, D., and Lyttle, J. D., Antistreptolysin titre of the serum in acute glomerular nephritis. Proc. Soc. Exper. Biol. and Med., 1933, 31, 211.

15. Swift, H. F., Hitchcock, C. H., Derick, C. L., and McEwen, C., Intravenous vaccination with streptococci in rheumatic fever. Am. J. M. Sc., 1931, $181,1$.

16. Swift, H. F., and Hodge, B. E., A simply prepared broth for producing hemolytic streptococcal hematoxin (streptolysin). Proc. Soc. Exper. Biol. and Med., 1933, 30, 1022.

17. Weiss, A., The prognostic value of the sedimentation rate in arthritis. A modification of the technique. Am. J. M. Sc., 1931, 181, 379.

18. Hodge, B. E., and Swift, H. F., Varying hemolytic and constant combining capacity of streptolysins; influence on testing for antistreptolysins. J. Exper. Med., 1933, 58, 277.

19. Todd, E. W., A comparative serological study of streptolysins derived from human and from animal infections, with notes on pneumococcal haemolysin, tetanolysin and staphylococcus toxin. J. Path. and Bact., 1934, 39, 299 